\title{
Regeneration Process of The Prosperous Justice Party (PKS) To Maintain Its Existence By Election Year 2014
}

\author{
Yusa Djuyandi ${ }^{1 *}$, Fifi Lutfiah Sodikin ${ }^{2}$ \\ ${ }^{1}$ Department of Politics, Padjadjaran University, Bandung, Indonesia \\ 2 Political Insight, Bandung, Indonesia \\ *Corresponding Author: yusa.djuyandi@unpad.ac.id
}

\begin{abstract}
ARTICLE INFO
\section{Publication Info:}

Research Article

How to cite:

Djuyandi, Y., E Sodikin, F. L. (2019). Regeneration Process of The Prosperous Justice Party (PKS) to Maintain Its Existence by Election Year 2014. Society, 7(1), 11-20.
\end{abstract}

DOI : $10.33019 /$ society.v7i1.72

Copyright (C) 2019. Owned by Author(s), published by Society

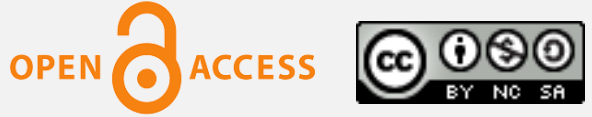

This is an open access article.

License: Attribution-

NonCommercial-ShareAlike (CC BY-NC-SA)

\begin{abstract}
Political parties prepare prospective national leaders through a political recruitment process. The Prosperous Justice Party (PKS), one of the Islamic parties In Indonesia, has a Regional Leadership Council (DPD) in each district or city. Regional Leadership Council (DPD) of Bandung City is interesting to study since it has a unique regeneration process and the organizations (under brow) have scored excellent cadres. This study aims to analyze the regeneration process of DPD PKS at Bandung City to maintain its existence in the 2014 election using the theory of political recruitment through the regeneration pathway proposed by Almond and Powell. The research was a qualitative method with data collection techniques carried out through secondary data collected by the General Elections Commission (KPU) of Bandung City. The primary data collected from PKS cadre interview process. This study found that the DPD PKS regeneration process of Bandung City affected the quality of promoted cadre, thus influencing the quality and existence of the party. The process of regeneration has produced excellent cadres through education and training stages that make it exist.
\end{abstract}

\section{Keywords: Existence; Regional Leadership Council; The Election Year 2014; The Process of Regeneration; The Prosperous Justice Party}

\section{Introduction}

The Prosperous Justice Party (PKS) is an Islamic Political party considered having a good strategy to select its candidate of cadres. Regeneration pattern is primary for the party in producing qualified cadres because they will be the next figures both in PKS itself and national leaders (Suroto dan Rudianto 2003; Tunjungsari, Lestari, and Sumarno 2017). 


\section{Regeneration Process of The Prosperous Justice Party (PKS) To Maintain Its Existence By Election Year 2014}

This article is to study the regeneration process running by The Regional Representative Council (DPD) of The Prosperous Justice Party (PKS) of Bandung City. The process runs three patterns, one of them is by involving the cadres to join political leadership training. The training is to prepare them comprehensively about knowledge of political parties, social issues, and other related to government. Besides, it also aims to produce qualified and Islamic characteristic cadres since they will be the next leaders both in public and internal party (PKS itself). ${ }^{1}$

Tight competition among political parties, moreover, new parties present with much political modality due to the pattern of relations or access to the media becomes a challenge for PKS to maintain the party exist in the 2014 election. One of its regeneration patterns Jamaah Tarbiyah (Islamic Proselytizer community) movement on Universities (Anismar 2014) begins to face intense competition. The old and the new parties begin to enter and strengthen their influence in universities by recruiting students as the young wing of the party through movements. The parties are not only doing socialization of their vision, mission and work program but also holding activities that can embrace student voters groups such as Leadership training to entrepreneurial seminar activities.

The Indonesian Democratic Party of Struggle (PDI Perjuangan) had already been networks in universities through the Indonesian National Student Movement (GMNI). However, it has begun using new strategies in embracing millennial groups through activities that are not engage with

\footnotetext{
${ }^{1}$ http://www.pikiran-rakyat.com/bandungraya/2016/11/25/pks-jawa-barat-gelar-sekolahkepemimpinan-partai-385846 (PKS Jawa Barat Gelar Sekolah Kepemimpinan Partai) 11 Juli 2018
}

politic. Not only that, the People's Conscience Party (Hanura) and the National Democratic Party (Nasdem) have also implemented a similar strategy with the Indonesian Democratic Party of Struggle (PDI Perjuangan). Therefore, to keep it exist, PKS begins to look at new activities in its pattern of regeneration (Juliano 2014).

As a political party based on religion, PKS has ordained as a $d a^{\prime} w a h$ party from the beginning, new activities in the regeneration pattern regarded as a brave movement. The party modifies its political movements and bore enormous consequences through reorganization and change the regeneration strategy pattern. its reorganization is carried out by taking into account important factors that come from society need and the context of democracy in Indonesia, by softening the line of ideology in the context of short-term strategic interests to gain votes.

PKS needs to show the public about how the party very concerns about issues that are in demand or demanded by the public, ranging from political and legal issues, such as anti-corruption issues and consistent in guarding good governance, to the issue of people`s economic development.

Aminuddin (2010) considered that the strategy provides a great advantage for PKS because if this party only moves to maintain the old ideological base, it will only get votes from its ideological voters only, while others will not.

This study is to discover how the regeneration process of the Prosperous Justice Party (PKS) in maintaining the party exist ahead of the 2014 General Election for Bandung City?

There are several studies or previous research that have proximity or relevance to this study. The first is a study by Anneu Dahliany (2012) entitled "Recruitment pattern of Political Party Leaders in 


\section{Regeneration Process of The Prosperous Justice Party (PKS) To Maintain Its Existence By Election Year 2014}

Increasing Political Parties work (Case Study in DPD PKS Bandung City)". The results of the study discuss the mechanism carried out by DPD PKS in Bandung City during the recruitment process of party leaders conducting Pemira (Great Election) with consideration from the Shura Majlis (consultative assembly or legislative body).

The second is a study by Akbar Sandro Yudho Dhiharso (2011) entitled "Cadre System among Islamic Parties (Study of Tarbiyah PKS in Yogyakarta)". The thesis discusses the Tarbiyah mechanism in the PKS as a condition and recruitment of prospective cadres.

And third is a study by Aminuddin (2010) regarding "Reorganizing the Prosperous Justice Party in Indonesia". This study explains more about the metamorphosis of PKS as part of a mediumterm strategy for mental constituent bases that step by step has begun to form and cover a wider area of social-political awareness.

Therefore, this research is broadening and enriching the literature from previous studies. The three previous studies do not discuss political parties that exist as a focus of research analysis.

This study explains how the regeneration process running by the DPD PKS of Bandung City produces qualified cadres and can maintain a mass base that influences on the party exist. Beside, Bandung City is the largest PKS base since the Governor of West Java elected for two periods.

Based on the background, this article will discuss and analyze in this paper are the cadre regeneration process of cadres that influences PKS exist.

\section{Theoretical Framework}

\section{The Function of Political Parties}

In countries that use a political system of democracy, the existence of political parties is considered important as a representation of representatives of community groups. The presence of political parties is very important in a modern and complex structure of society because political parties consider having the ability to channel complex political participation in society (Djuyandi 2018: 150).

Although political parties in constitutional democracies (liberal) and authoritarian countries (communists) play a different role, they have similar functions:

a. As political socialization, namely transmitting political culture in the framework of forming attitudes and orientations of community members as citizens (political education).

b. As political recruitment, namely the party selects and selects and appoints a person or group of people to carry out several roles in the political system in general, and the government specifically.

c. As political participation is to become a means of activity for the community in influencing the process of forming government leaders through elections and the creation or implementation of government policies.

d. As political communication, namely as the conveyer of information about politics from the government to the community and from the community to the government.

e. As political parties as a means of regulating conflict, namely helping to overcome or at least minimize the occurrence of conflict. This condition is also based on the view of Lijphart (1968) who said that the existence of differences or divisions at the lower

Copyright ( 2019. Owned by Author(s), published by Society. This is an open-access article under CC-BY-NC-SA license. 


\section{Regeneration Process of The Prosperous Justice Party (PKS) To Maintain Its Existence By Election Year 2014}

mass level can be overcome by cooperation between political elites. (Djuyandi 2018: 152-154).

Some of the functions of political parties above have in common with the views expressed by Budiardjo (2009: 405-409) that political parties in democratic countries have several functions, namely:
a. As a means of political communication.
b. As a means of political socialization.
c. As Political recruitment facilities.
d. As conflict management tools.

The difference between Djuyandi (2018) and Budiardjo (2009) related to their functions is in political participation function.

\section{Regeneration of Political Parties}

Based on one of the functions of the political party above, namely the function of political recruitment, that cannot be separated from that function, such regeneration process exist. The regeneration process is important for an organization as it in a political party, this reason is based on Harahap (2017: 1-2) which reveals that cadre, the party prepares or produces candidates who are ready to continue the baton of the struggle of an organization to become a leader in the future that is ready to run the organization.

Cadre preparation is carried out to educate someone to continue the baton of a party or organization (Partanto and AlBarry 1994: 293-294). In other words, the regeneration process is expected to produce cadres who can play an important role in an organization in the future.

In Western countries, regeneration to prepare political party leaders has been done very mature. Personal skills of cadres themselves play an important role, also, to support from the party (Parwadi 2006: 7). Cadres have a strategic position for the existence of political parties.

\section{Research Methodology}

The method used in this research is a qualitative method. Qualitative research is a method for exploring and understanding meaning derived from social and humanitarian problems. This method is considered appropriate for researching political parties, such as PKS because in addition to being able to describe a phenomenon in more detail it can also help this research to diagnose problems that occur. This study also uses a descriptive approach that allows describing how the regeneration process carried out by the DPD PKS in Bandung City as a party that has a strong enough exist in Bandung city.

The determination of case studies in qualitative methods is considered strategic in this study because it can investigate carefully an event or activity that occurs somewhere. In the case of studies, research can also choose suitable information and data to get maximum results (Creswell 2014: 278). With case studies, research can analyze the regeneration process carried out by PKS to get superior cadres who are wanted by the community and can carry out the objectives of the interests of political parties. Data collection in this study used the technique of determining informants by purposive or deliberately by the requirements required. The criteria for informant requirements are: (1) Having knowledge and understanding of the history and movement of the PKS; and (2) Having extensive knowledge and insight, and knowing and contributing to the regeneration process.

By choosing people who are considered to be the most knowledgeable of the information being studied, they are expected to be able to explore the object or social situation under study, then analyze the results of the research with the research theory.

Copyright (C) 2019. Owned by Author(s), published by Society. This is an open-access article under CC-BY-NC-SA license. 


\section{Regeneration Process of The Prosperous Justice Party (PKS) To Maintain Its Existence By Election Year 2014}

\section{Discussion and Result}

\section{PKS Regeneration in Da'wah movements}

PKS collaborates in various strengths to uphold the values and Islamic system that is Rahmatan lil alamin (mercy for the universe) and accelerator with the realization of civil society in Indonesia. With this mission, PKS began to expand Islamic da'wah and print cadres who could then develop Islamic social institutions in various fields as markaz taghyir (center of change) and solution center. The development carried out by PKS included campus missionary movement which was a movement calling for religion by students on campus. The missionary movement is transformed into a Student Activity Unit (UKM) or Campus Da'wah Institution (LDK) as a forum for all da'wah activities to expand networks. (Muhtadi 2012: 32-39).

The regeneration pattern for the Prosperous Justice Party is outlined in the Articles of Association (AD/ART) issued by the PKS Central Executive Board (DPP) Article 5 Chapter III. As for every member who registers voluntarily, they must be able to participate in every training held, and cadre formation carried out by the party.

Tarbiyah is a small group-based formation under the guidance of someone murabbi which is carried out through party non-formal activities. Tarbiyah plays an important role in the regeneration process. PKS underbrow organizations such as Garuda Keadilan (GK), Salimah Workers' Union (SPK), Indonesian Prosperous Fisheries Farmers Association (PPNSI), Indonesian Muslim Student Action Units (KAPMI), and Indonesian Muslim Students Action Unit (KAMMI) developed patterns and models individual regeneration. The groups that formally are not PKS under bow but ideologically have quite close to the PKS are Islamic Spirituality (Rohis) and Campus
Da'wah Institution (LDK). Both of them also developed a typical pattern of formation and cadre. The formal party cadre regeneration process is carried out officially by party management, which consists of seven levels, namely: TOP I (One Party Orientation Training), TOP II: TD I (Basic Training One), TD II: TL I (Advanced One Training), TL II, and Training in Social Management and Leadership (TMKS). This formal regeneration process is also a means of coaching as well as cadre gaps which will have implications for the distribution of roles and structure in PKS (Dhiharso, 2011).

\section{Implementation of Regeneration Strategy}

The regeneration process of DPD PKS in Bandung City was analyzed using Almond and Powell's theory of political recruitment. Almond and Powell's political recruitment theory emphasizes the selection of candidates for political party leaders and administrators by providing three paths as the process of running political recruitment. Almond and Powell's theory of political recruitment is different from other theories of political recruitment because this theory is an ongoing theory of political parties. Because it can be applied to the recruitment of prospective legislators so that it does not only look at the activities of political parties that carry out political recruitment activities. Besides, each pathway can be applied to a whole series of political party recruitment activities. Political parties can use political recruitment to improve regeneration activities starting from the selection process, improving and maintaining the quality of cadres, to produce superior cadres to improve party votes.

The process of political recruitment aims to produce qualified cadres by applying several qualification criteria. Before carrying out the political recruitment

Copyright (C) 2019. Owned by Author(s), published by Society. This is an open-access article under CC-BY-NC-SA license. 


\section{Regeneration Process of The Prosperous Justice Party (PKS) To Maintain Its Existence By Election Year 2014}

process, political parties naturally carry out a regeneration process to produce qualified cadres who can be placed as public officials through elections.

The regeneration process is a program that contains an activity of forming character and personality through a process of education and training that aims to produce qualified cadres. Through elections, political parties must submit candidates who are acceptable to the public so that they can increase the number of party votes.

Quality cadres have a very important role in the existence of political parties. People can get to know political parties through party activities carried out by their cadres. A qualified cadre can be a bridge for the community to channel their aspirations to the government. By maintaining public relations and trust, it is expected to increase its electability in Bandung City.

\section{a. Informal Regeneration}

Informal Kaderiasi in DPD PKS Bandung City is one of the efforts to give birth to superior and qualified cadres. This regeneration pattern is carried out in a long and long period. This long-term education was carried out by the DPD PKS cadres in Bandung City to their families, ranging from children to their teenage years. In addition to education, DPD PKS Bandung City also establishes a character for each candidate cadre and his family. Each cadre is given a guide to "10 Characteristics" which is a mainstay in the formation of personality and the application of Islamic values in everyday life to achieve the aspects needed to be able to compete. In informal regeneration there are principal values or points of application of regeneration that support regeneration success, namely:

1) Cadre Based on manual, such as Statutes/Articles of Association and specific guidelines used by political parties.

2) Regeneration through the family, the practice of applying direct regeneration to the families of each cadre.

3) Cadre Through Local Environment, there are two paths, such as vertical, where each cadre is tried to have another position and organize in a community environment, where they are expected to be able to make a positive contribution to the community. Then the horizontal path, each cadre must be able to prove and apply the learning outcomes that have been received to the environment of political parties.

\section{b. Formal Regeneration}

The formal regeneration process is an effort made by DPD PKS Bandung City in shaping an education that is implemented programmed and integrated to achieve the goals expected by the party. The formal regeneration process must follow a predetermined curriculum that is carried out within a certain period. DPD PKS Bandung City conducts evaluation activities based on a specified period to maintain and improve the quality of cadres as party representatives in the community.

The regeneration process has a positive value that can encourage and improve achievement by increasing competence and fair competition. DPD PKS Bandung City memorizes Al-Qur'an activities with a weekly period to foster motivation to develop themselves. This can increase cooperation between cadres by practicing together in reading and memorizing the AlQur'an. This teaches an important stage process that is spreading goodness to the people around beforehand before spreading goodness to the community.

Copyright (C) 2019. Owned by Author(s), published by Society. This is an open-access article under CC-BY-NC-SA license. https://doi.org/10.33019/society.v7i1.72 
1) The formal internal regeneration process is a regeneration process that aims as a leadership exercise. Each cadre is given alternate assignments to lead each other to give rise to a sense of responsibility as a leader and as a led cadre. DPD PKS Bandung City through the field of Human Resources is responsible for handling the process and implementation of Basic Leadership Training (LDK) activities. There are 2 stages of the process in implementing leadership exercises including (1) Members are initially led by young members, (2) Young members are led by middle members. Each member will have the opportunity to lead and be led at each stage of the process. Every stage of the leadership training process has an assessment report book as an evaluation and development material.

The workshop activity is a follow-up activity after leadership training activities. This activity is an activity agenda set by the center which aims to establish PKS cadres. This stage is a training step for each cadre to apply the knowledge gained during the training period. DPD PKS Bandung City has prepared various facilities for cadres to carry out these exercises. To maximize the results of education and training, DPD PKS Bandung City requires each cadre to carry out activities in the field. This aims as a means for cadres to apply the knowledge gained during education and training to the real conditions that occur in society.

2) The process of formal external regeneration is the process of selection stages as candidates for legislative and executive leaders. Each prospective cadre is given the obligation to participate and participate in activities held to become leaders for a certain time. One of them is by spreading goodness to the community. Through this process, it is expected to be able to produce qualified leaders who can show the party's background.

The DPD PKS of Bandung City does not question the prospective cadres from outside the party who do not have family relations. One of the main priorities of prospective cadres is expected to be a Khanif (good person). For example, PKS cadres in the Tasikmalaya area have made changes to someone so that someone is included in the PKS cadre section. This is an application or task that has been carried out by PKS cadres in the form of interactions with individuals or the community.

Gema Keadilan, one of the under brows who is active in the community, conducts activities to educate children, youth, youth, and society in general. Those who have interacted with PKS have also established communities on campus. As there are universities, if there are students who follow and apply PKS thoughts, it is the result of education from families who are part of the PKS or they have participated in coaching as a partnership with PKS.

\section{c. The Existence of DPD PKS Bandung City \\ DPD PKS Bandung City requires all} prospective cadres to become members first before participating in the regeneration process. In carrying out the regeneration process, prospective cadres must pass in performing obligations in the education process until they can be declared graduated.

The influence that the cadre has on the existence of political parties is very important. Cadres who will be known and 


\section{Regeneration Process of The Prosperous Justice Party (PKS) To Maintain Its Existence By Election Year 2014}

accepted by the community become the key to the existence of political parties. Besides, political party activities carried out with the community and inviting the public will make political parties more remembered by the community. PKS is an Islamic party with a level of existence that has reached a stage that is well known and known to the people of Bandung. Cadres who are promoted by PKS are cadres currently needed by the people of Bandung City. PKS cadres often carry out activities together with the community such as holding recitation activities or workshops for the community and other direct activities with the community.

The existence of political parties is also influenced by the presence of qualified cadres around the community so that they can make the community have the necessary leadership leaders. It is undeniable that the public still judges the person or person. DPD PKS Bandung City must prepare various levels of leadership that can be accepted by the community. The regeneration process is not an easy thing because many cadres who look good and are considered great by internal parties are not necessarily accepted by the community. Therefore DPD PKS Bandung City conducted an electability survey of prospective leaders. This activity is a means of measuring the ability of prospective leaders and accepting the opinions and desires of the community about the criteria needed by leaders.

DPD PKS Bandung City activities are considered acceptable in the community and able to increase the party's voice in the city. The approach was also carried out by all levels of prospective leaders prepared. Also, PKS cadres must maintain their idealism. PKS cadres must prioritize the people interests, not only personal interests. A direct approach to the community by PKS cadres will increasingly introduce PKS in the community.

The PKS voting base in Bandung City is the highest compared to other Islamic based parties. This was evidenced by the results of the vote in the legislative elections of the Bandung Regional Representatives in 2014. PKS Bandung City in 2014 got a valid vote of 136,983 and became an Islamic party with the most voted. Followed by the United Development Party (PPP) ranked in second place with a vote of 64,993 . Then the National Awakening Party (PKB) followed as in the third position with a total of 42,906 . PKS votes are very large compared to other Islamic party letters. Even as a whole PKS has succeeded in shifting nationalist-based parties such as the Party of Functional Groups (Golkar) and the Democratic Party (Demokrat). DPD PKS Bandung City became the third place as the most voted after the Indonesian Democratic Party of Struggle (PDI Perjuangan) and the Great Indonesia Movement Party (Gerindra). The difference in vote acquisition is not so great. This proves that the PKS supports base in Bandung is quite convincing. Based on these votes, the PKS of Bandung City won as many as 6 seats for Bandung Regional People's Representative Council in 2014 (KPU of Bandung City 2014).

DPD PKS Bandung City is known for its interesting in regeneration process, disaster response actions and faith-based activities that involve the local community. PKS is very close to the community through its qualified cadres. This illustrates that PKS as a political party has achieved sufficient existence.

\section{Conclusion}

The results showed that the resource person was very confident and believed in the regeneration process carried out by the

Copyright (C) 2019. Owned by Author(s), published by Society. This is an open-access article under CC-BY-NC-SA license.

https://doi.org/10.33019/society.v7i1.72 


\section{Regeneration Process of The Prosperous Justice Party (PKS) To Maintain Its Existence By Election Year 2014}

DPD PKS in Bandung City to produce qualified and accepted cadres in the community. The regeneration process is carried out based on guidelines that have been made nationally. DPD PKS Bandung City has an interesting regeneration process compared to other political parties, especially Islamic political parties. From The theory of political recruitment, the regeneration process of DPD PKS of Bandung City runs well. On the other hand, there are several different implementations. In other words, the DPD PKS of Bandung City improvised in several parts of the regeneration process. This is done to achieve the party's vision, mission, and goals.

DPD PKS Bandung City runs the regeneration process informally and formally. Qualified cadres present is very influential on the party exist among people. Therefore, the DPD PKS of Bandung City carried out a regeneration process to produce excellent cadres needed by the community and political parties. The regeneration process carried out by the PKS DPD in Bandung City reached a good level because each cadre spreads a positive side to the family so that good things related to religion can make someone closer to God.

DPD PKS Bandung City has carried out the regeneration process by producing cadres that enthusiasm in community activities. DPD PKS Bandung City fully understands that by improving the quality and capabilities of cadres can maintain the party exist. The existence is measured by the vote and the victory of political parties in the General Election as well as the results of the political party coalition victory as long as it benefits the PKS. Also, the growing number of members is an indicator of the existence of political parties. This is because PKS is a political party that is considered to be a party that is in line with political thoughts that are built personally by cadres. (Almond 2000).

\section{References}

Almond, A. (2000). Sosialisasi Politik Budaya Politik dan Rekrutmen Politik dalam Mocthae Masoed dan Colin Mac Andrews. Yogyakarta: Universitas Gadjah Mada Press.

Aminuddin, M. (2017). Reorganisasi Partai Keadilan Sejahtera di Indonesia.

Sumber:

https://ww.researchgate.net/publication/2 77967941.

Anismar, E. (2014). Kaderisasai pada Basis Sosal Partai Keadilan Sejahtera (PKS) di Perguruan Tinggi (Studi Kasus Jamaah Tarbiyah UI). Skripsi. Jakarta: Fakultas Ilmu Sosial dan Ilmu Politik, Universitas Indonesia.

Budiardjo, M. (2009). Dasar-dasar Ilmu Politik. Jakarta: Gramedia Pustaka Utama.

Cecep, W. (2016). PKS Jawa Barat Gelar Sekolah Kepemimpinan Partai. Sumber: https://www.pikiranrakyat.com/bandung-

raya/2016/11/25/pks-jawa-barat-gelarsekolah-kepemimpinan-partai-385846.

Creswell, J. (2014). Research Design Pendekatan Metode Kualitatif, Kuantitatif, dan Campuran. Yogyakarta: Pustaka Pelajar.

Dahliany, A. (2012). Pola Rekrutmen Pemimpin Partai Politik Dalam Meningkatkan Kriteria Partai Politik (Studi Kasus di DPD PKS Kota Bandung). Bandung: Universitas Pendidikan Indonesia.

Dhiharso. (2011). Sistem Pengkaderan di Kalangan Partai Islam (Studi tentang Tarbiyah PKS Yogyakarta). Yogyakarta: Universitas Islam Negeri Sunan Kalijaga. 


\section{Regeneration Process of The Prosperous Justice Party (PKS) To Maintain Its Existence By Election Year 2014}

Djuyandi, Y. (2018). Pengantar Ilmu Politik. Depok: Rajawali Pers.

Firdaus, R. (2014). Pengaruh Rekrutmen Partai Politik Terhadap Kepemimpinan Pemerintah di Kabupaten Sukabumi Tahun 2005-2010 (Studi Terhadap Bupati Drs. H. Sukamawijaya, MM yang berlatar belakang kader PKS). Bandung: Universitas Padjadjaran.

Harahap, I. (2017). Kaderisasi Partai Politik dan Pengaruhnya Terhadap Kepemimpinan Nasional. Jurnal Politik, Hlm. 1-9. Sumber: http://repository.bakrie.ac.id/id/eprint/12 46.

Juliano, S. (2014). Seminar Strategi Kampanye Partai Politik Menjelang Pemilihan Umum Tahun $2014 . \quad$ Sumber: http://fisip.unikom.ac.id/id/page/seminarstategi-kampanye-politik-2014.html.

Muhtadi, B. (2012). Dilema PKS. Jakarta: Gramedia.

Partanto, P. A. \& Barry, M. D. (1994). Kamus Ilmiah Populer. Surabaya: Arloka.

Purwadi, R. (2006). "Kaderiasasi Organisasi dalam Perubahan". Jurnal Wawasan, Vol. 12 (1), Hlm. 1-10.

Rahadi, F. (2014). Kota Bandung Basis Suara PKS.

Sumber: https://nasional.republika.co.id/berita/nas ional/jawa-baratnasinal/14/03/13/n2d7ei-survei-kotabandung-basis-suara-pks.

Suroto \& Rudianto, D. (2003). Partai Politik di Indonesia. Jakarta: PT. Citra Mandala Pratama.

Tunjungsari, A.R., Lestari, P., \& Sumarno. (2017). “Gerakan Dakwah sebagai Sistem Kaderisasi Partai Keadilan Sejahtera (Studi pada Dewan Pengurus Wilayah PKS Provinsi Jawa Tengah". Unnes Political Science Journal, Vol. 1 (1), Hlm. 21-28.

\section{About the Authors}

1. Yusa Djuyandi obtained his Doctoral Degree in Politics with Cumlaude at Padjadjaran University, Bandung, Indonesia. He was a lecturer in Department of Communication, Bina Nusantara University, Jakarta, Indonesia (2010-2017), Specialized Staff for Commission 1, Member of Parliement, The House of Representatives of the Republic of Indonesia (2006-2009), and a reseacher at Indonesia Institute for Defense and Strategic Studies (LESPERSSI) (2009present). Now Yusa Djuyandi is a lecturer at Department of Politics, Padjadjaran University and he is also a head of The Centre of National and Global Security Studies at Padjadjaran University.

2. Fifi Lutfiah Sodikin obtained her Bachelor Degree in Politics at Padjadjaran University, Bandung, Indonesia, in 2018. Now she is a researcher at Political Insight (Polsight), Bandung, Indonesia.

Copyright (C) 2019. Owned by Author(s), published by Society. This is an open-access article under CC-BY-NC-SA license. https://doi.org/10.33019/society.v7i1.72 